\title{
Exploring Factors Related to Self-perceived Hearing Handicap in the Elderly with Moderate to Moderately-severe Hearing Loss
}

\author{
Youngmee Lee ${ }^{\mathrm{a}}$, Sungil Park ${ }^{\mathrm{b}}$, Soo Jung Lee ${ }^{\mathrm{c}}$ \\ aDepartment of Communication Disorders, Ewha Womans university, Seoul, Korea \\ ${ }^{b}$ Park Sungil Aural Rehabilitation and Speech Center, Busan, Korea \\ 'Department of Speech-Language pathology and Audiology, Tongmyong University, Busan, Korea
}

Correspondence: Soo Jung Lee, $\mathrm{PhD}$ Department of Speech-Language pathology and Audiology, Tongmyong University, 428 Sinseon-ro, Nam-gu, Busan 48520, Korea

Tel: $+82-51-629-2138$

Fax: +82-51-629-2019

E-mail: sjslp@tu.ac.kr

Received: December 30, 2019

Revised: February 2, 2020

Accepted: February 3,2020
Objectives: The aims of this study were to compare the performance related to audiometric, cognitive function, and depression variables between the elderly with mild-to-moderate hearing handicap and the elderly with severe hearing handicap, to identify which factors are correlated with their self- perceived hearing handicap, and to determine which factors can distinguish the elderly with mild-to-moderate hearing handicap from the elderly with severe hearing handicap. Methods: A total of 22 elderly patients with moderate to moderately-severe hearing loss participated in this study. The Korean version of the Hearing Handicap Inventory for the Elderly (K-HHIE) was administered to obtain their hearing handicap scores. All patients underwent audiometric, cognitive function, and depression assessments. Results: We found a significant differences in the average hearing threshold, sentence recognition scores in noise, and depression scores between the two groups. The scores of the K-HHIE significantly correlated with the average hearing threshold, sentence recognition scores in noise, and depression scores in all elderly patients with hearing loss. In the logistic regression analysis, sentence recognition scores of $+5 \mathrm{~dB}$ SNR were a significant factor for differentiating between the two groups. Conclusion: The hearing threshold, speech perception in noise, and depression level are significantly associated with self-perceived hearing handicap in the elderly with moderate to moderately-severe hearing loss. These results indicate that audiometric and depression assessments are need to provide appropriate auditory-habilitation services for cognitively normal elderly with moderate to moderately-severe hearing loss.

Keywords: Factors, Self-perceived hearing handicap, Elderly, Moderate to moderately-severe hearing loss
United Nations (UN)에서는 만 65세 이상의 노인 인구 비율이 전체 인구의 $7 \%$ 이상이면 고령화 사회(aging society), $14 \%$ 이상이 면 고령 사회(aged society), $20 \%$ 이상일 경우에는 초고령 사회 (post-aged society)로 분류하고 있다. 2018년 통계청의 자료에 따르 면, 우리나라의 노인 인구는 전체 인구의 $14.3 \%$ 에 해당하여 고령 사회로 진입하였다(Statistics Korea, 2018). 무엇보다 우리나라는 다른 나라에 비해 고령화가 매우 빠른 속도로 진행되고 있어서, 노 인과 관련된 만성질환, 의료 및 재활, 복지 등과 관련된 현황 파악,
연구, 의료 및 보건 관련 정책 마련이 시급한 상태이다.

난청(hearing loss)은 관절염 다음으로 노인에게서 나타나는 흔 한 만성 질환 중의 하나로, 노인 인구의 약 $33 \%$ 가 중등도(moderate) 혹은 고도(severe) 난청을 겪고 있다(Gates, Cooper, Kannel, \& Miller, 1990; Goman \& Lin, 2016; Kim \& Yeo, 2015; Kim et al., 2000). 임상 현장에서는 순음청력검사(pure-tone audiometry)의 $0.5,1,2,4 \mathrm{kHz}$ 의 청력 역치(hearing threshold)를 4 분법 혹은 6 분 법으로 평균 청력 역치를 산출하여 난청을 진단한다. 이때, 양측 귀 
의 평균 청력 역치가 $26 \mathrm{~dB} \mathrm{HL}$ 이상의 감각신경성 난청이면서, 양 측 귀의 청력 손실이 대칭적인 경우에 노인성 난청(presbycusis)을 진단한다. 국외 연구(Agrawal, Platz, \& Niparko, 2008)에서는 65-74 세 인구의 약 $25-30 \%, 75$ 세 이상의 인구의 약 $50 \%$ 에서 노인성 난청 이 발생된다고 보고하였다. 국내 질병건강관리본부(2012)에서는 $65-74$ 세 인구의 약 $25 \%, 75$ 세 이상 인구의 약 $50 \%$ 에서 난청이 발생 한다고 보고하였다. 우리나라는 이미 고령 사회로 진입하였기 때문 에, 향후 노인성 난청의 인구는 점차로 증가할 것으로 전망된다(Lee, Hwang, \& Jang, 2014).

노인성 난청은 청각 기관의 노화로 발생되는 난청이며, 청력 역치 의 상승과 함께 중추신경계의 말소리 처리 능력이 함께 저하되는 증상을 보인다(Kim \& Yeo, 2015). 노인성 난청은 초기에는 고주파 수대역의 청력이 저하되기 시작하며, 점차적으로 저음과 중간음역 대까지 청력이 저하된다. 일반적으로 남성이 여성에 비해서 고주파 수대역에서의 청력 저하가 급격하게 진행되며, 노인성 난청을 경험 하는 남성의 수가 여성에 비해서 많고, 청력 손실의 정도도 남성이 여성보다 더 심각한 양상을 보인다(Morrell, Gordon-Sarant, Pearson, Brant, \& Fozard, 1996). 노인성 난청은 청력 저하 속도가 초기 에는 서서히 진행되기 때문에, 노인성 난청을 경험하는 당사자는 본인이 난청이 있는지를 지각하지 못한 채 본인의 청력 저하 상태에 적응하기도 한다. 그런데, 나이가 들수록 청력 저하 속도가 급격히 빨라지기 때문에, 난청으로 인해 가족 및 친구들로부터 사회적, 정 서적 고립감을 느끼고, 난청 개선에 대해 자포자기한 채로 적응하 면서 지내기도 한다(Kim \& Yeo, 2015; Lee et al., 2014). 특히, 난청 노인은 다양한 듣기 상황에서 상대방의 말을 이해하는데 어려움 을 겪게 되며, 심지어 조용한 상황에서도 여러 사람과 대화를 나누 는데 어려움을 겪는다(Humes \& Christopherson, 1991; Lee \& Kim, 2016). Pichora-Fuller, Schneider와 Daneman (1995)은 난청 노인이 동일한 청력을 지닌 청년에 비해서 소음 조건에서의 말지각이 유의 하게 낮다고 보고하면서, 난청 노인은 말초계 외에 중추계의 청각 관련 기관의 노화가 함께 진행되어 난청 청년에 비해서 말소리를 처 리하는 능력이 떨어진다고 언급하였다. 즉, 노화로 인한 인지 저하 가 난청과 함께 소음 조건에서의 말지각에 부정적인 영향을 미치는 것이다. 그리고 노인은 난청 외에도 술, 담배와 같은 환경적인 요인, 유전적인 감수성, 내과적 질환 등이 악화되면서 타인과 대화할 기 회가 줄어들기 때문에, 의사소통과 관련된 사회심리적 어려움을 겪기도 한다(Choi \& Chung, 2011).

세계보건기구(World Health Organization, WHO)에서는 청각 장애를 신체적인 결함, 즉 청력 손실의 문제로만 한정하지 않고, 청 력 손실로 인한 사회 참여 제한, 정서적인 좌절감 등으로 개인이 겪
는 다양한 듣기의 어려움으로 규정하였다(WHO, 1980, 2001). 즉, 난청 노인이 겪는 듣기 어려움의 정도는 청력 역치와 반드시 정비례 하는 것이 아니며, 여러 요인들에 의해서 복합적인 양상으로 나타 낼 수 있는 것이다. 노인성 난청은 청력 역치와 같은 청각학적 변인 만으로 개개인이 겪고 있는 일상생활에서의 듣기 및 사회심리적인 어려움의 정도를 판단하기 어렵기 때문에, 난청 노인 당사자가 지각 하는 청각장애 정도를 파악하여야 재활 서비스 제공에 필요한 정 보를 파악할 수 있다(Chang, Ho, \& Chou, 2009). 그러므로, 난청 노 인이 주관적으로 지각하는 청각장애지수를 정량적으로 평가하여 본인, 가족, 사회로부터 적절한 지원을 받도록 할 필요가 있다(Ventry \& Weinstein, 1982). 이러한 이유로, 국외에서는 난청 노인의 청 각장애지수를 평가하기 위한 고령자 청력 장애 검사(Hearing Handicap Inventory for the Elderly, HHIE; Ventry \& Weinstein, 1982)가 개발, 표준화되었으며, 미국 언어청각협회(American Speech-Language-Hearing Association, ASHA)에서는 노인을 대상으로 난청 을 선별하는 검사로 $\mathrm{HHIE}$ 를 사용할 것을 권고하기도 하였다.

난청 노인의 주관적 청각장애지수에 관한 선행 연구(Chang et al., 2009; Hong \& Lee, 2002; Weinstein \& Ventry, 1983)를 살펴보 면, 청력 역치가 청각장애지수와 유의한 상관이 있다고 보고하였 다. Chang 등(2009)이 65세 이상의 대만 노인의 청력 역치와 청각 장애지수와의 관련성을 살펴본 결과, 두 변인 간에 보통 수준의 유 의한 상관을 보였다. Hong과 Lee (2002)가 국내 65세 이상의 난청 노인을 대상으로 청력 역치와 청각장애지수와의 관련성을 살펴본 결과, 난청 노인의 청력 역치가 증가할수록 청각장애지수도 증가하 였으며, $2 \mathrm{kHz}$ 의 청력 역치가 청각장애지수와 관련성이 높았다. Weinstein과 Ventry (1983)의 연구에서도 난청 노인의 청력 역치와 청각장애지수는 보통 수준의 상관이 있는 것으로 나타났다. 이처 럼, 난청 노인의 청력 역치와 주관적 청각장애지수 간에 보통 수준 의 상관을 보였다는 선행 연구의 결과는 청각적 변인 외에 다른 변 인들이 난청 노인의 청각장애지수에 영향을 미칠 수 있다는 것을 의미한다. Lee (2018)는 인지장애가 있는 경도 난청 노인과 인지장 애가 없는 경도 난청 노인의 청각장애지수를 비교한 결과, 인지장 애가 있는 난청 노인이 인지장애가 없는 난청 노인에 비해 청각장애 지수가 높았다고 보고하였다. Lee, Kim, Kim, Kim과 Park (2019) 은 인지장애가 없는 경도 난청 노인의 청력 역치와 교육연수가 청각 장애지수와 유의한 상관이 있으며, 인지장애가 있는 경도 난청 노 인은 소음 조건에서의 말지각과 전두엽 집행기능(frontal-executive function)이 청각장애지수와 유의한 상관이 있다고 하였다. 그리고 Ferrai 등(2019)은 후천성 난청 성인의 청각장애지수가 일상생활에 서의 스트레스, 우울감과 같은 사회심리적인 변인과 상관이 높다고 
Youngmee Lee, et al. • Self-perceived Hearing Handicap in the Elderly with HL

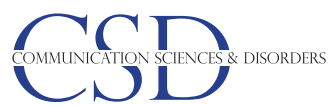

보고하기도 하였다.

난청 노인의 주관적인 청각장애지수가 난청 노인의 상담, 보청기 (hearing aid) 착용, 인공와우이식(cochlear implantation), 재활 접 근법 결정 등에 중요한 정보를 제공하므로, 주관적 청각장애지수 가 높은 노인과 낮은 노인 간에 유의한 차이를 발생시키는 변인을 확인하고, 난청 노인의 청각장애지수와 관련이 있는 변인을 탐색하 는 것은 매우 중요하다. 선행 연구 $(\mathrm{Ku} \& \mathrm{Kim}, 2010 \mathrm{a} ; \mathrm{Ku} \& \mathrm{Kim}$, $2010 b)$ 에서 보청기를 착용한 난청 노인의 청각장애평가지수(Korean evaluation scale for hearing handicap)를 보고한 바 있다. 하지 만, 상당 수의 선행 연구에서는 난청 노인의 청력수준이나 보청기 착용과 같은 청각학적 변인을 모두 통제하지 않은 상태에서 청각장 애지수를 보고하거나 난청 노인의 특정 변인에만 초점을 맞추어서 청각장애지수를 분석하고 있다. 이에 따라, 본 연구에서는 일상생 활에서 보청기를 착용하고 있는 중등도, 중등고도 난청 노인만을 대상으로 하여, 주관적 청각장애지수가 경도-중등도인 노인과 심 도인 노인의 청각적, 인지기능, 우울 관련 변인의 수행력을 비교하 고, 난청 노인의 주관적 청각장애지수와 청각적, 인지기능, 우울 관 련 변인 간의 관련성을 탐색하며, 난청 노인의 청각장애지수의 중 증도(severity)를 구분하는 유의한 변인이 무엇인지 살펴보고자 하 였다. 본 연구의 목적을 위한 구체적인 연구 질문은 다음과 같다.

첫째, 청각장애지수가 경도-중등도인 노인 집단과 심도인 노인 집단 간에 청각 변인(평균 청력 역치, 소음 조건에서의 문장인지 점 수), 인지기능 변인(선별적 인지능력, 전두엽 집행 능력), 우울 변인 (노인성 우울 정도)의 수행력에 유의한 차이가 있는가?

둘째, 청각 변인(평균 청력 역치, 소음 조건에서의 문장인지 점 수), 인지기능 변인(선별적 인지능력, 전두엽 집행 능력), 우울 변인 (노인성 우울 정도) 가운데, 전체 난청 노인의 청각장애지수와 유의 한 상관이 있는 변인은 무엇인가?

셋째, 난청 노인의 청각장애지수의 중증도(경도-중등도 집단, 심 도 집단)를 구분하는 유의한 변수는 무엇인가?

\section{연구방법}

\section{연구대상}

본 연구는 65 세 이상의 난청 노인 22명(남성 15 명, 여성 7명)을 대 상으로 하였다. 대상자의 선정기준은 (1) 대상자의 연령이 만 65세 이상이며, (2) 순음청력검사 결과, 양측의 평균 청력이 41-69 dB HL 에 속하는 중등도 및 중등고도 감각신경성 난청이며(Clark, 1981), (3) 기초건강선별 설문에서 신경학 혹은 정신학적 질환의 병력이 없 으며, (4) 한국판 간이정신상태검사(Korean Mini-Mental State Ex- amination, K-MMSE)의 점수가 연령 및 교육연수 규준의 -1 표준 편차 이내의 정상 범주에 속하고(Kang, 2006), (6) 교육연수가 6년 이상이며, (7) 과제 수행을 위한 시각 능력을 보유하고 있고, (8) 일 측 혹은 양측에 보청기를 착용한 경우이다.

본 연구에서는 주관적인 청각장애 지수에 따른 인구학적 변인, 청각 변인, 인지기능 변인, 우울 변인에 유의한 차이가 있는지 살펴 보기 위해서, 한국어판 고령자 청력 장애 검사(Korean version of Hearing Handicap Inventory for the Elderly, K-HHIE)의 중증도 기준(절단점수: 44점)에 따라서 대상자를 경도-중등도 집단과 심 도 집단으로 구분하였다(Hong \& Lee, 2002; Souza \& Lemos, 2015; Weinstein \& Ventry, 1983). 집단 간 통제가 잘 이루어졌는지 확인 하기 위해서, 독립표본 $t$-검정과 카이제곱(chi-square) 검정을 실시 하였다. 그 결과, 연령 $\left(t_{(20)}=-.186, p>.05\right)$, 교육연수 $\left(t_{(20)}=-.071, p>.05\right)$, 보청기 사용기간 $\left(t_{(20)}=-.209, p>.05\right)$, 하루 평균 보청기 착용시간 $\left(t_{(20)}=-.318, p>.05\right), \mathrm{K}-\mathrm{MMSE}$ 점수 $\left(t_{(20)}=-6.711, p>.05\right)$, 성별 $\left(\chi_{(1)}^{2}=\right.$ $.028, p>.05)$ 에서 집단간 유의한 차이가 없었다. K-HHIE 점수에서 는 집단 간에 유의한 차이가 있었다 $\left(t_{(20)}=-6.711, p<.001\right)$. 두 집단 에 대한 대상자의 정보는 Table 1에 제시하였다.

\section{연구 과제}

\section{청각장애지수 평가}

본 연구에서는 난청 노인이 주관적으로 지각하는 청각장애의 정 도를 평가하기 위해서, K-HHIE를 사용하였다(Park et al., 2011). K$\mathrm{HHIE}$ 는 난청이 노인의 일상생활에 미치는 영향을 기능적으로 평 가하기 위한 목적으로 개발한 HHIE (Ventry \& Weinstein, 1982) 를 번안한 것으로, 국내에서 난청 노인 169명을 대상으로 신뢰도와 타당도를 검증하여 표준화되었다. 본 검사는 난청 노인의 보청기 착용 이득, 청능재활 효과, 청각장애 정도를 정량화할 수 있으며, 영

Table 1. Participants' characteristics

\begin{tabular}{lcc}
\hline & $\begin{array}{c}\text { Mild-to-moderate group } \\
(\mathrm{N}=12)\end{array}$ & $\begin{array}{c}\text { Severe group } \\
(\mathrm{N}=10)\end{array}$ \\
\hline Sex (M:F) & $8: 4$ & $7: 3$ \\
Age (yr) & $77.50 \pm 4.54(70-88)$ & $77.90 \pm 5.55(71-87)$ \\
Education (yr) & $9.50 \pm 3.29(6-16)$ & $9.60 \pm 3.34(6-16)$ \\
Hours of use HAs per day & $8.25 \pm 9.86(2-16)$ & $8.80 \pm 3.88(2-14)$ \\
Duration of use HAs (yr) & $1.56 \pm 1.83(0.8-1.8)$ & $1.27 \pm 0.43(0.9-1.8)$ \\
K-MMSE & $28.08 \pm 1.08(26-29)$ & $27.60 \pm 1.43(24-29)$ \\
K-HHIE & $22.34 \pm 12.81(4-42)$ & $67.00 \pm 18.34(44-90)$ \\
\hline
\end{tabular}

Values are presented as mean \pm standard deviation (range). $\mathrm{M}=$ male; $\mathrm{F}=$ female; $\mathrm{HAs}=$ hearing aids; $\mathrm{K}-\mathrm{MMSE}=$ Korean Mini-Mental State $\mathrm{Ex}$ amination (Kang, 2006); K-HHIE= Korean version of Hearing Handicap Inventory for the Elderly (Park et al., 2011). 
어 사용권에서는 높은 타당도와 신뢰도를 검증받아 이미 임상현장 과 연구분야에서 널리 활용되고 있다(Ku \& Kim, 2000; Han, Lee, Koo, \& Kim, 2015; Park et al., 2011). K-HHIE는 사회/상황적 특성 12 문항과 정서적 특성 13 문항으로, 총 25 문항으로 구성되어 있다 (Appendix 1). 대상자는 전문가와의 인터뷰(face-to-face interview) 나 직접 지필(paper-pencil) 방식으로 각 문항에 '예', '가끔', '아니 오' 중 하나로 답변한다. 이때, 문항별 대상자의 응답에 따라 '예'는 4점, '가끔'은 2점, '아니오'는 0점으로 채점하며, 총점은 문항별 점 수를 합산하여 0 점에서 100 점으로 산출한다. 해당 검사의 점수를 토대로, 난청으로 인한 대상자의 주관적인 장애 정도를 해석할 수 있다. 즉, 대상자의 점수가 0 점에서 16 점까지는 청각장애를 자각하 지 않는 것으로, 18 점부터 42 점까지는 경도-중등도의 청각장애를 지각하고 있는 것으로, 44점 이상은 심각한 수준으로 청각장애를 지각하고 있는 것으로 해석할 수 있다(Hong \& Lee, 2002; Souza \& Lemos, 2015; Weinstein \& Ventry, 1983).

\section{청력 검사}

대상자의 청력 상태를 확인하기 위해서, 임피던스 청력검사(impedance audiometry), 순음청력검사(pure tone audiometry, PTA), 어음청력검사(speech audiometry)를 실시하였다. 먼저, 임피던스 청력검사(Interacoustics AT235 Tympanometry Middler Ear Analyzer, Middelfart, Denmark)를 실시하여 대상자의 중이(middle ear) 상태가 정상적인지 확인하였다. 그 다음, 순음청력검사(Interacoustics AD629 Audiometry, Middelfart, Denmark)를 통하여,

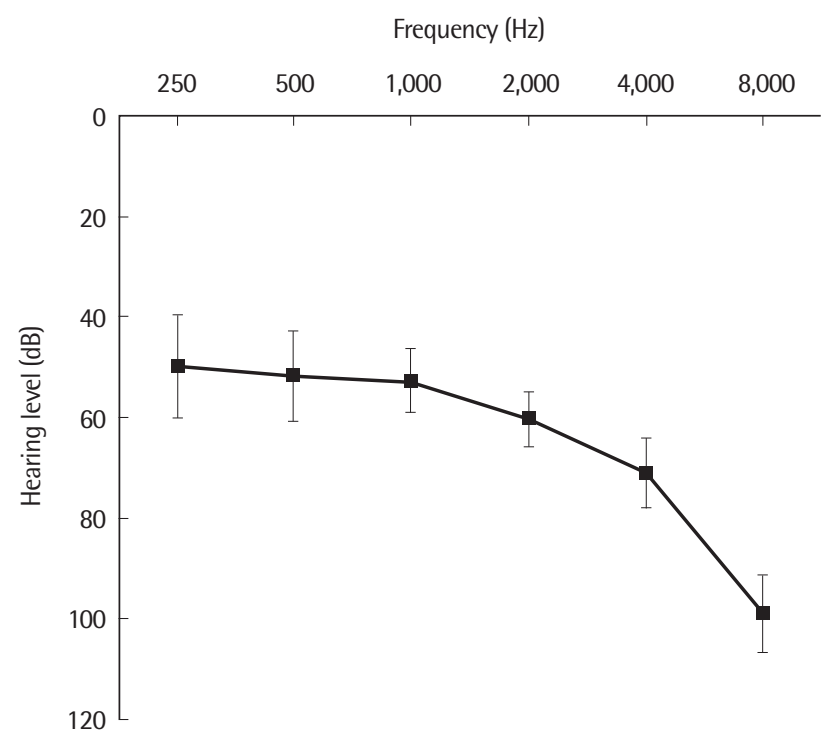

Figure 1. Average of unaided hearing threshold of the better hearing ear at each frequency in elderly with hearing loss.
$0.5,1,2,4,8 \mathrm{KHz}$ 의 어음 주파수에 따른 대상자의 기도 및 골도 청 력 역치를 측정하였다(Figure 1). 평균 청력 역치는 대상자의 양측 귀 중에서 더 나은 청력의 귀를 기준으로 하여, 주요 주파수인 1,2 $\mathrm{KHz}$ 에 가산점을 부과하는 6 분법을 이용하여 산출하였다. 마지막 으로 어음청력검사에서는 양양격 단어(spondee word)를 이용하 여 대상자의 어음청취역치를 측정하였다. 이때, 대상자가 편안하게 들을 수 있는 쾌청수준의 어음강도(most comfortable loudness level)도 함께 측정하였다.

\section{말지각 검사}

대상자의 소음 조건에서의 말지각(speech perception)을 평가하 기 위해서, 한국어음청력검사(Korean Speech Audiometry, KSA) 의 성인용 한국표준문장표를 사용하였다(Lee et al., 2010). 성인용 한국표준문장표는 총 8 개의 목록으로 구성되어 있으며, 각 목록에 는 성인에게 친숙한 문장 10 개로 구성되어 있다. $\mathrm{KSA}$ 의 목록들은 음소 빈도와 분포, 어휘 친숙도, 문장 구조 및 길이, 주파수 측면에 서 목록 간 균형화가 검증되어 있어서, 어떤 목록을 선택하더라도 동일한 난이도로 대상자의 말지각을 평가할 수 있다.

본 연구에서 소음 조건에서 말지각 검사를 실시하였으며, 방음 실 사운드필드에서 대상자에게 개별적으로 진행하였다. 본 연구에 서 사용한 소음 유형은 다화자 잡음(multi-talker babble)이었으며, 신호대잡음비(signal-to-noise ratio, SNR)는 $0 \mathrm{~dB} \mathrm{SNR,}+5 \mathrm{~dB}$ SNR 로 설정하였다(Choi, 2009). 검사자는 청력검사기(Interacoustics AD629 Audiomertry, Middelfart, Denmark)를 통해 육성(live voice) 으로 대상자의 쾌청수준에서 맞추어서 문장을 $0 \mathrm{~dB} \mathrm{SNR},+5 \mathrm{~dB}$ $\mathrm{SNR}$ 로 제시하였다. 이때, 대상자는 방음실에서 본인의 정면을 기 준으로 $1 \mathrm{~m}$ 위치한 스피커에서 나오는 문장을 듣고 따라 말하였다. $\mathrm{KSA}$ 채점은 각 목록 내 핵심 단어(40개) 중 대상자가 따라 말한 핵 심 단어의 총점을 백분율로 환산하였다.

\section{인지기능 검사}

본 연구에서 대상자의 인지 기능을 평가하기 위해서, 선별적 인 지능력, 전두엽 집행기능(frontal-executive function)을 평가하였다.

\section{선별적 인지기능}

대상자의 선별적 인지능력을 평가하기 위해서 K-MMSE (Kang, 2006)을 시행하였다. 본 검사는 짧은 시간 안에 시간 및 장소 지남 력, 단기 기억력, 주의 집중, 언어 능력 등의 다양한 인지 요소를 평 가할 수 있다. K-MMSE의 총점은 30점이며, 대상자의 연령과 교육 수준에 따른 규준을 확인할 수 있다. 
Youngmee Lee, et al. • Self-perceived Hearing Handicap in the Elderly with HL

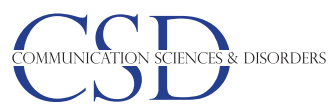

전두엽 집행기능

대상자의 전두엽 집행기능을 평가하기 위해서, 통제 단어 연상 검사, 스트룹 검사, 기호 잇기 검사를 실시하였다.

통제 단어 연상 검사: 전두엽 집행기능을 평가하는 검사들 중 하 나인 한국어판 통제 단어 연상 검사(Korean version of Controlled Oral Word Association Test, K-COWAT)의 하부 검사인 동물 이 름대기 과제를 사용하였다(Kang, Chin, Na, Lee, \& Park, 2000). 본 연구에서는 제한된 시간(1분) 동안 대상자가 '동물'에 해당되는 단 어를 최대한 많이 산출하도록 하여, 대상자가 말한 단어의 개수로 점수를 산출하였다. 이때, 대상자가 같은 단어를 여러 번 말했을 경 우에는 1번만 정반응으로 인정하였으며, 동물 범주에 속하지 않은 단어는 점수에서 제외하였다.

기호 잇기 검사: 전두엽 집행기능을 평가하는 검사들 중 하나인 한국판 노인형 기호 잇기 검사(Korean version of Trail Makig Test for Elderly, K-TMT-E)를 사용하였다(Lee, 2006). K-TMT-E는 제한 된 시간(300초) 동안 1 부터 15 까지의 숫자를 순서대로 연결하는 A 형 과제와 숫자와 요일을 순서대로 번갈아 가면서 연결하는 B형 과 제로 구성된다. 검사 점수는 $\mathrm{A}$ 형과 $\mathrm{B}$ 형 과제의 수행시간(초)과 오 류 개수로 산출하였다.
스트룹 검사: 전두엽 집행기능을 평가하는 검사들 중 하나인 한 국판 색상 단어 스트룹 검사(Korean-Color Word Stroop Test, KCWST)를 사용하였다(Lee, Kang, \& Na, 2000). 본 검사는 글자 읽 기와 색깔 읽기 과제로 구성되며, 두 과제 모두 제한된 시간(2분) 안 에 112 개의 자극을 읽도록 하였다. 글자 읽기와 색깔 읽기 과제의 점수는 각각 정반응 수와 정반응 항목 당 반응시간(초)로 산출하였 으며, 색깔 읽기 과제의 반응시간에서 글자 읽기 과제의 반응시간 을 뺀 간섭점수도 함께 산출하였다.

\section{우울 검사}

본 연구에서는 축약형 한국어판 노인성 우울증 척도(Short foam of Geriatric Depression Scale, Korean version, SGDS)를 사용하여 (Cho et al., 1999), 대상자의 우울 정도를 평가하였다. Yesavage 등 (1983)이 총 30개의 문항으로 구성된 노인 우울증 척도(Geriatric Depression Scale, GDS)를 개발하였다. GDS의 30 개 문항이 노인 들에게 적용하기에는 다소 시간이 많이 걸려서, Sheikh와 Yesavage (1986)가 15문항으로 줄인 SGDS를 제작하였다. SGDS는 기존의 GDS와의 상관관계가 높으며, 노인의 우울증 선별에서 민감도와 특이도가 유사한 것으로 보고되고 있다(Alden, Austin, \& Stur-

Table 2. Results of audiometric, cognitive, and depressive tests for mild-to-moderate and severe groups

\begin{tabular}{lcc}
\hline Tasks & Mild-to-moderate group (N=12) & Severe group (N=10) \\
\hline Audiometric variables & & $61.92 \pm 6.91(47.5-69.17)$ \\
Average hearing threshold (dB HL) & $53.68 \pm 9.86(41.67-67.5)$ & $22.50 \pm 20.78(0.00-55.00)$ \\
Sentence recognition score of O dB SNR (\%) & $57.08 \pm 27.57(7.50-90.00)$ & $45.50 \pm 25.92(7.50-82.50)$ \\
Sentence recognition score of +5 dB SNR (\%) & $76.46 \pm 16.04(40.00-92.50)$ & $13.60 \pm 3.31(10.00-20.00)$ \\
Cognitive function variables & & $29.60 \pm 9.89(18.00-50.00)$ \\
K-COWAT & $12.33 \pm 3.87(5.00-18.00)$ & $0.00 \pm 0.00(0.00-0.00)$ \\
Semantic fluency & & $63.70 \pm 31.65(21.00-111.00)$ \\
K-TMT-E & $26.17 \pm 10.62(15.00-46.00)$ & $0.80 \pm 0.79(0.00-2.00)$ \\
Part A: reaction time (sec) & $0.00 \pm 0.00(0.00-0.00)$ & $111.10 \pm 1.85(106.00-112.00)$ \\
Part A: number of errors & $45.00 \pm 21.49(24.00-92.00)$ & $90.40 \pm 25.54(55.00-120.00)$ \\
Part B: reaction time (sec) & $0.67 \pm 0.89(0.00-2.00)$ & $74.90 \pm 27.25(36.00-111.00)$ \\
Part B: number of errors & & $120.00 \pm 0.00(120.00-120.00)$ \\
K-CWST & $108.58 \pm 9.29(80.00-112.00)$ & $0.75 \pm 0.21(0.46-1.00)$ \\
Word reading: number of correct response & $79.17 \pm 21.42(61.00-120.00)$ & $8.10 \pm 3.96(1.00-13.00)$ \\
Word reading: reaction time (sec) & $85.83 \pm 19.17(54.00-112.00)$ & $118.25 \pm 4.35(106.00-120.00)$ \\
Color reading: number of correct response & $0.67 \pm 0.18(0.52-1.00)$ & \\
Color reading: reaction time (sec) & & $2.75 \pm 3.41(0.00-11.00)$ \\
Interference score & &
\end{tabular}

Values are presented as mean \pm standard deviation (range).

SNR= signal-to-noise ratio; K-COWAT = Korean version of Controlled Oral Word Association Test (Kang et al., 2000); K-TMT-E= Korean version of Trail Making Test for elderly (Lee, 2006); K-CWST = Korean version of Color Word Stroop Test (Lee, Kang, \& Na, 2000); SGDS=Short form of Geriatric Depression Scale, Korean version (Cho et al., 1999). 
geon, 1989; Cho et al., 1999). SGDS는 자기 보고형 우울 척도로, 대 상자는 총 15 개의 문항에 대해서 '예', '아니오로 응답할 수 있다. SGDS는 대상자의 응답에 대해 '예'는 1점, '아니오'는 0점으로 채점 하여 점수가 0 점에서 15 점까지 산출될 수 있으며, 점수가 높을수록 우울 증상이 심한 것으로 해석한다.

\section{연구 절차}

본 연구에서 사용한 검사는 조용한 장소에서 대상자에게 개별 적으로 실시하였다. 먼저, 대상자의 선별을 위해서 개인정보와 기초 건강에 대한 설문, 순음청력검사 및 임피던스 청력검사, K-MMSE 검 사를 실시하였다. 대상자 선정기준에 부합할 경우, K-HHIE 및 SGDS 설문 검사, 인지기능 평가를 실시하였다. 대상자에게 설문을 실시 하는 방식(예, 인터뷰 방식, 지필방식)에 따라서 응답 결과가 상이할 수 있는 점을 고려하여, 본 연구에서는 모든 대상자에게 인터뷰 방 식으로 K-HHIE, SGDS 설문 검사를 진행하였다. 대상자의 모든 반
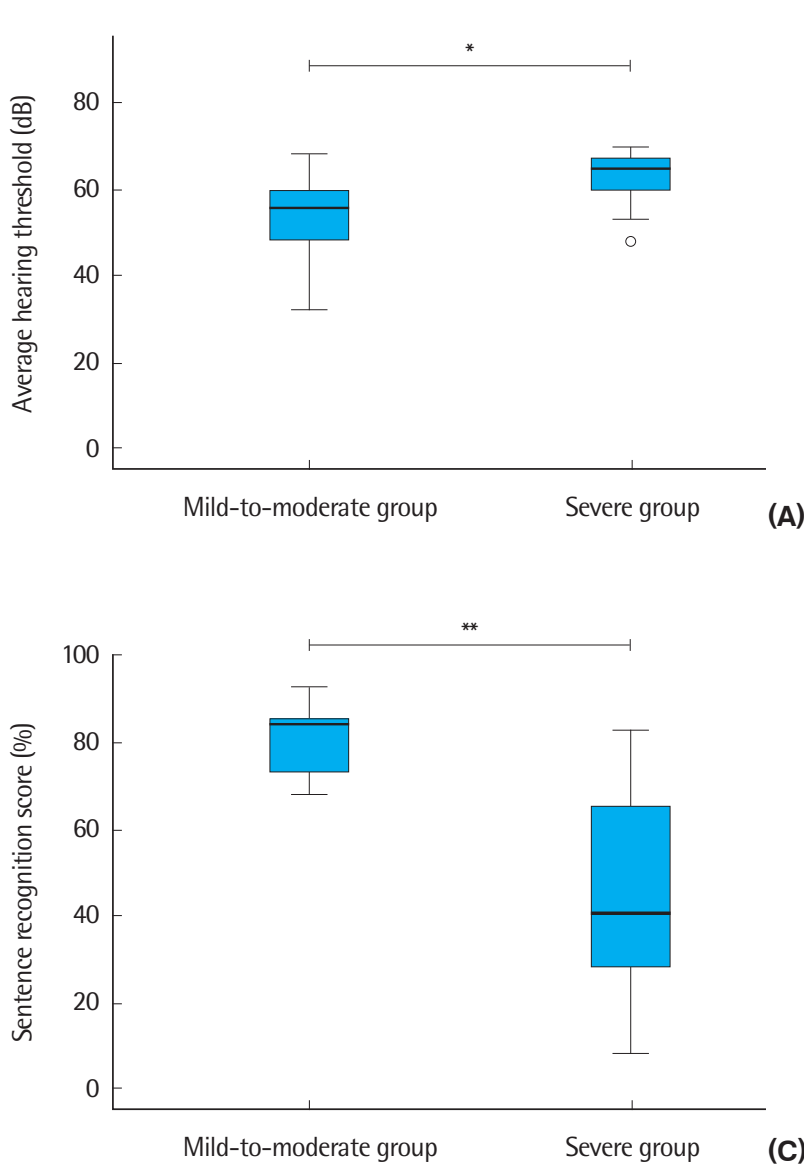

응은 실시간으로 기록하였으며, 신뢰로운 결과 분석을 위해서 디지 털레코더(EDIROL R-09HR; Roland Corp., Los Angeles, CA, USA) 를 사용하여 녹음하였다.

\section{자료 통계적 처리}

수집된 자료의 정규성을 확인하기 위해서 일표본 콜모고로프스미르노프 검정(one-sample Kolmogorov-Smirnov test) 실시하였 다. 그 결과, $0 \mathrm{~dB} \mathrm{SNR},+5 \mathrm{~dB}$ SNR에서의 KSA 점수, SGDS 점수가 정규분포 가정을 만족하지 않았다. 이에 따라, 상관 분석과 집단 간 비교분석에서는 비모수 통계방법을 사용하였다. 첫째, 주관적 청각 장애지수가 경도-중등도인 집단과 고도인 집단 간에 유의한 차이를 보이는 변수를 살펴보기 위해서, 맨-휘트니 $U$-검정(Mann-Whitney $U$-test)을 실시하였다. 둘째, 난청 노인의 주관적 청각장애지수, 인구학적 변인, 청각 변인, 인지기능 변인, 우울 변인과의 상관을 살 펴보기 위해서, 스피어만 등위상관분석(Spearman rank correla-
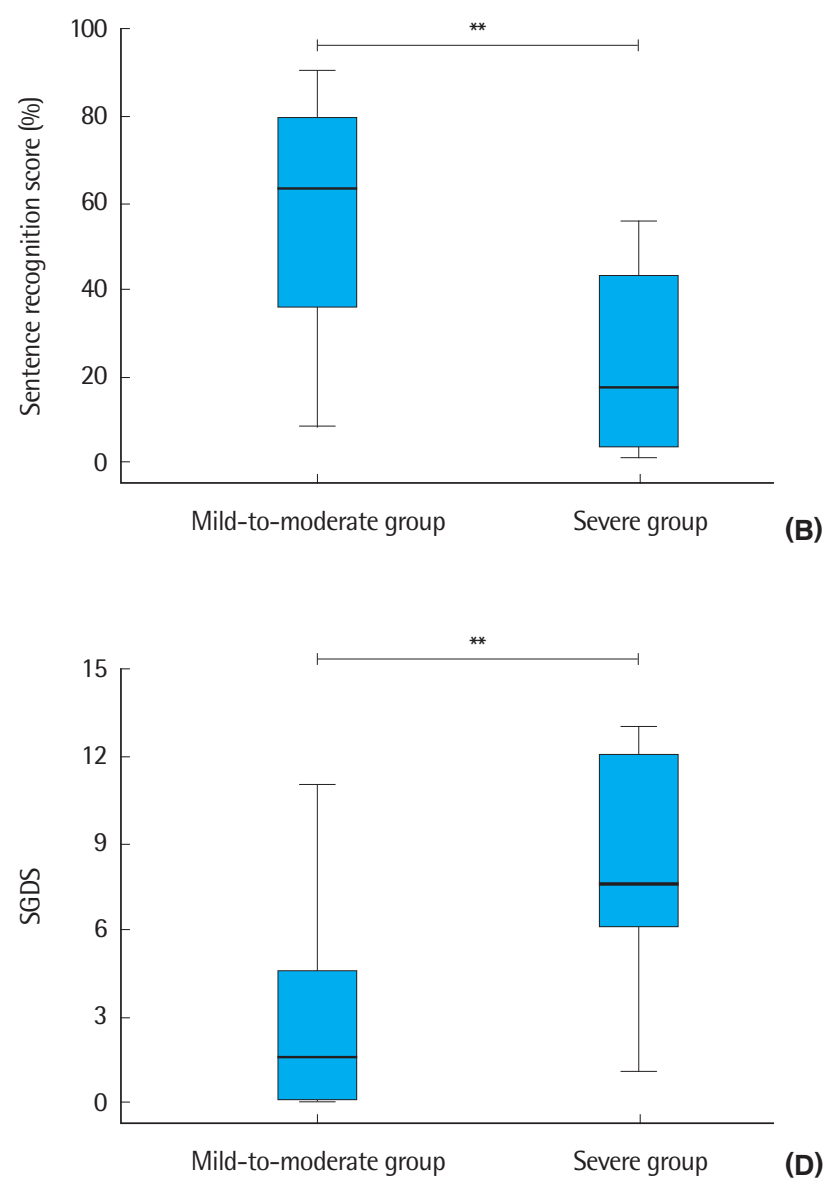

Figure 2. Comparison of the average hearing threshold (A), sentence recognition scores of $0 \mathrm{~dB} S N R(B)$, sentence recognition scores of $+5 \mathrm{~dB} S N R(C)$, and scores of short form of geriatric depression scale (D) between mild-to-moderate group and severe group. ${ }^{*} p<.05,{ }^{* *} p<.01$. 
Youngmee Lee, et al. • Self-perceived Hearing Handicap in the Elderly with HL

tion)을 통해 상관계수를 분석하였다. 마지막으로, 난청 노인의 주 관적 청각장애지수의 중증도를 구분하는 변인을 살펴보기 위해서, 이항 로지스틱 회귀분석(binary logisitic regression analysis)을 실 시하였다. 본 연구에서의 자료 분석을 위해서, IBM SPSS Statistics version 24 (IBM Co., Armonk, NY, USA) 프로그램을 이용하였으 며, 유의수준은 .05 미만으로 설정하였다.

\section{연구결과}

\section{집단에 따른 청각, 인지기능, 우울 변인의 수행력 비교}

난청 노인의 주관적 청각장애지수에 따른 청각, 인지기능, 우울

Table 3. Results of audiometric, cognitive, and depressive tests for mild-tomoderate and severe groups

\begin{tabular}{ll}
\hline Variables & K-HHIE score \\
\hline Demographic variables & .111 \\
Age & .061 \\
Education & \\
Audiometric variables & $.480^{*}$ \\
Average hearing threshold & .054 \\
Hours of use HAs per day & $-.699^{* * *}$ \\
Sentence recognition score of 0 dB SNR & $-.700^{* * *}$ \\
Sentence recognition score of +5 dB SNR & \\
Cognitive function variables & -.026 \\
K-MMSE & \\
K-COWAT & .397 \\
Semantic fluency & \\
K-TMT-E & .154 \\
Part A: reaction time & .000 \\
Part A: number of errors & .379 \\
Part B: reaction time & .263 \\
Part B: number of errors & \\
K-CWST & .080 \\
Word reading: number of correct response & .047 \\
Word reading: reaction time & -.312 \\
Color reading: number of correct response & .148 \\
Color reading: reaction time & \\
Interference score & \\
Depression variable & \\
SGDS & \\
\hline
\end{tabular}

$\mathrm{K}-\mathrm{HHIE}=$ Korean version of Hearing Handicap Inventory for the Elderly (Park et al., 2011); HAs=hearing aids; SNR= signal-to-noise ratio; K-MMSE=Korean MiniMental State Examination (Kang, 2006); K-COWAT=Korean version of Controlled Oral Word Association Test (Kang et al., 2000); K-TMT-E=Korean version of Trail Making Test for elderly (Lee, 2006); K-CWST = Korean version of Color Word Stroop Test (Lee, Kang, \& Na, 2000); SGDS= Short form of Geriatric Depression Scale, Korean version (Cho et al., 1999).

${ }^{*} p<.05,{ }^{* * *} p<.001$.
관련 변인의 수행력에 대한 기술통계 결과는 Table 2에 제시하였다. 맨-휘트니 $U$-검정을 실시한 결과, 대상자의 평균 청력 역치 $(U=$ $28.50, p<.05), 0 \mathrm{~dB}$ SNR에서의 문장인지 점수 $(U=18.50, p<.01)$, $+5 \mathrm{~dB} \mathrm{SNR}$ 에서의 문장인지 점수 $(U=14.00, p<.01)$, SGDS 점수 $(U=16.00, p<.01)$ 에서 청각장애지수가 경도-중등도 집단과 고도 집단 간에 유의한 차이가 있었다(Figure 2). 인지기능 변인과 관련 된 K-COWAT, K-TMT-E, K-CWST의 수행력에서는 집단 간 유의 한차이가 없었다(all $p>.05)$.

\section{난청 노인의 주관적 청각장애지수와 관련 변인 간의 관계}

스피어만 등위상관분석을 실시한 결과, 전체 대상자의 K-HHIE 점수와 대상자의 평균 청력 역치 $(r=.480, p<.05), 0 \mathrm{~dB} \mathrm{SNR}$ 에서의 문장인지 점수 $(r=-.699, p<.001),+5 \mathrm{~dB}$ SNR에서의 문장인지 점 수 $(r=-.700, p<.001), \mathrm{SGDS}$ 점수 $(r=.519, p<.05)$ 간의 상관관계 가 유의하였다(Table 3).

\section{난청 노인의 주관적 청각장애지수의 중증도 구분에 영향을 미치는 변인}

이항 로지스틱 회귀분석 모델에서는 K-HHIE 점수와의 상관이 유의하게 나타난 평균 청력 역치, $0 \mathrm{~dB}$ SNR에서의 문장인지 점수, $+5 \mathrm{~dB}$ SNR에서의 문장인지 점수, SGDS 점수를 독립변수로, 청각 장애지수가 경도-중등도 집단과 고도 집단을 종속변수로 입력하 였다. 그 결과, 로지스틱 회귀분석 모델은 통계적으로 유의하였으며 $\left(\chi_{(1)}^{2}=9.295, p<.01\right)$, 난청 노인의 청각장애지수의 중증도를 구분 하는 유의한 변수는 $+5 \mathrm{~dB} \mathrm{SNR}$ 소음 조건에서의 문장인지 점수로 나타났다(Wald's $\chi_{(1)}^{2}=6.511, p<.05$, odds ratio $=.937$ ). 즉, $+5 \mathrm{~dB}$ $\mathrm{SNR}$ 조건의 문장인지 점수가 높을수록 경도-중등도 집단으로 분 류되었으며 $(\beta=-.065, p<.05)$, 분류 정확도는 $72.7 \%$ 였다.

\section{논의 및 결론}

본 연구에서는 일상생활에서 보청기를 착용하는 난청 노인이 주 관적으로 지각하는 청각장애지수를 평가하여 청각장애지수의 중증 도에 따른 집단 간에 인구학적, 청각적, 인지기능, 우울 변인에서 유 의한 차이가 있는지를 살펴보고, 난청 노인의 청각장애지수와 유 의한 상관을 보이는 변인이 무엇인지 탐색하며, 난청 노인의 청각장 애지수의 중증도를 구분하는 유의한 변수가 무엇인지 확인하였다.

청각장애지수의 중증도에 따른 집단 간에 유의한 차이가 있는 변인을 살펴보기 위해서, 본 연구에서는 선행 연구(Hong \& Lee, 2002; Souza \& Lemos, 2015; Weinstein \& Ventry, 1983)에서 제시 
한 절단 점수를 기준으로 하여, 난청 노인의 K-HHIE 점수가 18-42 점인 경도-중등도 집단과 44점 이상인 고도 집단으로 구분하였다. 인구학적, 청각적, 인지기능, 우울 관련 변인 중에서, 두 집단 간에 평균 청력 역치 $0 \mathrm{~dB}$ SNR과 $+5 \mathrm{~dB}$ SNR에서의 문장인지 점수, 우 울 점수가 유의한 차이를 보였다. 고도 집단의 평균 청력 역치와 우 울 점수가 경도-중등도 집단에 비해서 유의하게 높았으며, 고도 집 단의 $0 \mathrm{~dB} \mathrm{SNR}$ 과 $+5 \mathrm{~dB}$ SNR 에서의 문장인지 점수는 경도-중등 도 집단에 비해서 유의하게 낮았다.

전체 난청 노인의 청각장애지수는 평균 청력 역치 $0 \mathrm{~dB}$ SNR과 $+5 \mathrm{~dB}$ SNR에서의 문장인지 점수, 우울 점수가 K-HHIE 점수와 유 의한 상관을 보였다. 본 연구에서는 난청 노인의 평균 청력 역치와 K-HHIE 점수 간의 상관계수가.480로, 난청 노인은 청력 손실이 심 해질수록 듣기 어려움과 사회적 고립이 더 심각해지는 것으로 지각 하고 있었다. 이는 난청 노인의 청력 역치와 청각장애지수 간에 상관 이 있다고 보고한 선행 연구(Chang et al., 2009; Hong \& Lee, 2002; Lutman, Brown, \& Coles, 1987; Stewart, Scherer, \& Lehman, 2003; Weinstein \& Ventry, 1983)의 결과와 일치한다. 난청 노인의 언어, 문화, 사용한 검사가 다르더라도 청력 역치와 주관적으로 지각하 는 청각장애지수와 관련이 있게 나타나서, 노화로 인한 말초 청각 수준에서의 청력 손실 정도가 듣기 어려움과 사회 및 정서적 고립 과 관련이 있다는 것으로 해석할 수 있다. Chang 등(2009)은 중국 과 대만에 거주하는 난청 노인의 청력 역치와 청각장애지수와의 상 관계수가 다른 연구에 비해서 낮게 나타난 것에 주목하면서, 난청 노인의 속한 사회와 문화에 따라서 노인의 청각장애지수에는 차이 가 나타날 수 있다고 언급하였다. 즉, 난청을 노화의 자연스러운 과 정으로 받아들이고 노인에 대한 공경심이 높고 의료 및 복지 지원 이 풍부한 사회에서 생활하는 노인이 그렇지 않은 사회에서 생활 하는 노인에 비해 청각장애지수가 낮게 나타날 수도 있는 것이다.

청력 역치 외에도 $0 \mathrm{~dB} \mathrm{SNR}$ 과 $+5 \mathrm{~dB}$ SNR에서의 문장인지 점수 도 난청 노인의 K-HHIE 점수와 유의한 상관을 보였다. 난청 노인의 소음 조건에서의 문장인지 점수가 낮을수록 본인의 청각장애를 더 심각하게 지각하고 있었다. 이러한 결과는 K-HHIE 문항의 특성과 관련이 있을 것으로 생각된다. 예를 들면, K-HHIE의 문항에는 "누 군가 속삭일 때 알아듣기가 어렵습니까?”, “청력 이상으로 TV나 라디오를 들을 때 어려움을 느끼십니까?”와 같이 일상생활에서의 듣기 어려움에 대해서 묻고 있다. 이처럼, K-HHIE의 일부 문항이 난청 노인이 일상생활에서 경험하는 듣기 어려움에 초점을 맞추고 있기 때문에, 문장인지 점수가 K-HHIE의 점수와 높은 상관을 보 였을 수 있다. 문장인지능력이 타인과 구어 의사소통을 하기 위한 필수적인 언어처리과정인 것을 감안할 때, 난청 노인의 말지각 평가
시 청력과 언어-인지 능력과 같은 청자 요인 외에도 소음과 관련된 같은 환경적 요인을 함께 고려할 필요가 있겠다.

$+5 \mathrm{~dB} \mathrm{SNR}$ 에서의 문장인지 점수만이 난청 노인의 청각장애지수 의 중증도를 구분하는 유의한 변인으로 나타났다. 즉, $+5 \mathrm{~dB} \mathrm{SNR}$ 에서의 문장인지 점수가 높을수록 청각장애지수가 고도인 집단보 다는 경도-중등도인 집단으로 분류되는 경향을 보였다. 소음 조건 에서의 문장인지검사는 청력 손실로 인한 일상생활에서의 듣기 어 려움을 실제적으로 평가하기 때문에, 난청 노인의 청각장애지수의 중증도 구분에 영향을 미쳤을 것으로 생각된다. 여기서 흥미로운 점은 동일한 소음 유형을 사용하여 문장인지검사를 실시하였다고 하더라도 신호대잡음비에 따라서 난청 노인의 청각장애지수의 중 증도 구분에 미치는 정도에 차이가 있다는 것이다. 즉, 소음과 문장 자극이 같은 강도로 제시되는 $0 \mathrm{~dB} \mathrm{SNR}$ 조건보다는 문장 자극이 소음보다 더 큰 강도로 제시되는 $+5 \mathrm{~dB} \mathrm{SNR}$ 조건에서의 문장인지 점수가 난청 노인의 청각장애지수의 중중도를 구분하는데 더 유용 한 것으로 나타났다. Shojaei, Ashayeri, Jafari, Dast, 그리고 Kamali (2015)는 신호대잡음비가 난청 노인의 말지각에 영향을 미치기 때 문에, 임상에서 말지각 검사 시 적절한 신호대잡음비를 선택하는 것이 중요하다고 언급하였다. Jang과 Jeon (2015)은 정상청력 성인 조차 $0 \mathrm{~dB} \mathrm{SNR}$ 조건에서 낮은 단어인지 점수를 보였다고 보고하면 서, 어음인지검사를 난청 성인에게 적용할 때는 $0 \mathrm{~dB}$ SNR 조건이 적절하지 않을 수 있다고 하였다. McArdle과 Wilson 그리고 Burks (2005)는 다화자 잡음이 배경 소음으로 제시할 경우에는 신호대잡 음비를 $+4.3 \mathrm{~dB}$ SNR로 설정하여 문장인지검사를 하는 것이 적절 하다고 하였다. 그리고 $\mathrm{Wu}$ 등 (2018)이 경도 및 중등도 난청 노인이 경험하는 일상적인 듣기 상황에서의 신호대잡음비를 분석한 결과, 신호대잡음비가 2-14 dB SNR인 경우가 전체 듣기 상황의 $62.9 \%$ 에 해당하였으며, $0 \mathrm{~dB} \mathrm{SNR}$ 이하인 경우는 7.5\%에 불과하였다.

본 연구에서는 난청 노인의 우울 점수와 K-HHIE 점수와 유의한 상관을 보여서, 우울 정도가 심각할수록 본인의 청각장애를 더 심 각하게 인식하고 있었다. 이러한 결과는 $\mathrm{WHO}$ 에서 난청을 청력 손 실과 같은 신체적 기능 저하의 측면으로만 생각하기 보다는 난청으 로 인한 사회 참여의 제약, 고립감 등의 측면도 함께 생각해야 한다 는 견해를 지지하는 결과이다. Chun, Cho와 Cho (2005)가 65세 이 상의 정상청력 노인과 난청 노인을 대상으로 한국어판 노인성 우 울증 검사를 실시한 결과, 난청 노인이 정상청력 노인에 비해서 우 울 정도가 심각했으며, 난청의 정도가 심할수록 우울 점수가 높아 지는 경향을 보였다. 노인성 난청에 관심을 가지는 전문가들은 난청 이 타인과의 대화를 단절시키는 의사소통 장애 외에도 사회심리적 인 장애와도 관련이 있기 때문에, 노인 복지 차원에서 난청의 진단 
Youngmee Lee, et al. • Self-perceived Hearing Handicap in the Elderly with HL

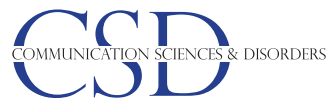

및 예방, 청능재활에 대한 관심이 높아져야 한다고 의견을 모으고 있다(Choi \& Chung, 2011; Ferrai et al., 2019; Kim \& Yeo, 2015). Ciorba, Bianchini, Pelucchi와 Pastore (2012)는 노인성 난청이 듣기 어려움, 의사소통 단절, 우울과 분노, 신체 질환 등과 관련이 있으 며, 노년의 삶의 질에도 부정적인 영향을 미친다고 하였다. Ferrai 등(2019)도 난청이 일상생활에서의 스트레스, 우울 및 고립과 같은 사회심리적인 변인과 관련이 높다고 하였다.

본 연구에서 난청 노인의 인지기능 관련된 변인은 청각장애지수 에 따른 집단 비교와 상관분석 모두에서 유의하지 않은 것으로 나 타났다. 이는 난청 노인의 인지 기능의 저하가 청각장애지수에 부정 적인 영향을 미칠 수 있다고 보고한 선행 연구(Lee, 2018; Zekveld, George, Houtgast, \& Kramer, 2013)의 연구와 일치하지 않는 결과 이다. 선행 연구와 본 연구와의 결과 차이는 대상자의 특성과 관련 이 있을 것으로 생각된다. Lee (2018)는 인지장애를 동반한 난청 노 인과 인지장애를 동반하지 않은 난청 노인의 청각장애지수를 비교 하였으나, 본 연구에서는 인지기능 선별 검사에서 정상 범주에 속 하는 난청 노인만을 대상으로 인지기능 변인과 청각장애지수와의 관련성을 분석하였다. 이처럼, 난청 노인을 대상으로 인지기능과 청 각장애지수와의 관련성을 살펴보더라도, 대상자의 특성에 따라서 인지기능이 노인의 듣기 및 사회심리적 어려움에 미치는 영향은 달 라질 수 있다. 최근에는 난청과 치매(dementia)와의 유의한 상관관 계가 보고되면서, 둘 간의 기저처리과정에 관한 연구, 난청의 조기 진단 및 예방, 재활에 대한 관심이 높아지고 있다(Uchida et al., 2019). Livingston 등(2017)은 난청을 초기에 발견하는 것만으로도 치매 발생 위험이 $9 \%$ 감소할 수 있다고 보고하였다. 노화로 인해서 말초 신경계와 중추신경계의 기능 저하가 함께 진행되는 것을 고려해서, 임상 현장에서는 난청 노인에게 인지선별검사를 필수적으로 진행 하고 인지기능 저하 정도에 따라서 청능재활 프로그램을 수정, 보 완할 필요가 있을 것이다.

본 연구를 통해서, 중등도 및 중등고도 난청 노인의 청력 역치, 소 음 조건에서의 문장인지 점수, 우울 정도가 청각장애지수와 관련 이 있다는 것을 확인하였다. 그리고 $+5 \mathrm{~dB}$ SNR에서의 문장인지 점 수가 난청 노인의 청각장애지수의 중증도를 구분하는 유의한 변인 으로 나타나서, 연령, 난청 유무, 일상생활에서의 듣기 상황을 고려 한 신호대잡음비로 말지각을 평가하는 것이 중요하다는 것을 확인 하였다. 청력 역치와 소음 조건에서의 말지각과 같은 청각 변인이 난청 노인의 주관적인 듣기 어려움과 심리사회적 측면과 관련이 있 으므로, 난청 노인의 청각장애지수를 줄이기 위한 난청의 조기 진 단 및 예방, 보청기 착용, 청능재활 참여 등과 같은 의료, 보건, 복지 정책이 마련되어야 할 것이다. 나아가 임상 현장에서는 청력검사 결
과만으로 난청 노인의 듣기 어려움을 단편적으로 판단하지 말고, 소음 조건에서의 말지각 검사를 함께 실시하여 적절한 상담과 효 과적인 청능재활 프로그램을 적용하여야 할 것이다. 특히, 노인성 난청이 의사소통 문제에만 국한되지 않고 스트레스, 불안, 우울 등 과 같은 심리적인 부분에도 영향을 미치는 복합적인 증상이라는 것을 확인하였다. 상당 수의 청능재활 전문가는 듣기 향상에 초점 을 맞추어 난청 노인의 재활 프로그램을 진행하고 있지만, 우울, 불 안 등과 같은 심리적인 부분의 평가, 정신의학 및 상담 전문가와 협 력하여 재활을 진행하는 방법도 모색해야 할 필요가 있다. 본 연구 에서는 보청기를 착용한 노인을 대상으로 청력 역치와 소음 조건에 서의 말지각 점수만을 청각 변인으로 하여, 난청 노인의 청각장애 지수와의 관련성을 살펴보았다. 난청 노인의 청능재활에서 보청기 착용, 보청기 착용 역치(aided hearing threshold), 보청기 착용 시 간, 보청기 만족도 등과 같은 보청기와 관련된 요인들이 중요한 것 을 고려한다면, 향후 연구에서는 보청기와 관련된 변인들을 난청 노인의 듣기 어려움 및 기타 변인들과의 관련성을 탐색해볼 필요가 있겠다. 본 연구는 대상자의 수가 적으며, 인지기능이 정상적이고 교육연수가 6년 이상이며 보청기를 착용하고 있는 건강한 노인들 을 대상으로 하였기 때문에, 일반적인 난청 노인에게 연구 결과를 일반화하는데 제한이 있다. 향후에는 사회경제적 지위, 보청기 착 용 유무, 인지 기능이 다양한 난청 노인의 주관적 청각장애지수를 평가하고 관련 요인을 탐색할 필요가 있으며, 난청 노인의 청각장애 지수를 낮출 수 있도록 중요한 관련 요인들이 고려된 청능재활 프 로그램을 개발하고 재활 효과를 검증하는 연구도 진행되어야 할 것이다.

\section{REFERENCES}

Agrawal, Y., Platz, E. A., \& Niparko, J. K. (2008). Prevalence of hearing loss and differences by demographic characteristics among US adults: data from the national health and nutrition examination survey, 1999-2004. Archives of Internal Medicine, 168(14), 1522-1530.

Alden, D., Austin, C., \& Sturgeon, R. (1989). A correlation between the geriatric depression scale long and short forma. Journal of Gerontology, 44(4), 124-125.

Chang, H. P., Ho, C. Y., \& Chou, P. (2009). The factors associated with a selfperceived hearing handicap in elderly people with hearing impairmentresults from a community-based study. Ear and Hearing, 30(5), 576-583.

Cho, M. J., Bae, J. N., Suh, G. H., Hahm, B. J., Kim, J. K., Lee, D. W., \& Kang, M. H. (1999). Validation of geriatric depression scale, Korean version (GDS) 
in the assessment of DSM-III-R major depression. Journal of Korean Neuropsychiatric Association, 38(1), 48-63.

Choi, H. S. (2009). The effects of noise type and signal-to-noise ratio on sentence recognition performance (Master's thesis). Hallym University, Chuncheon, Korea.

Choi, J., \& Chung, W. H. (2011). Age-related hearing loss and the effects of hearing aids. Journal of the Korean Medical Association, 54(9), 918-924.

Chun, H. T., Cho, S. H., \& Cho, S. J. (2005). A study of geriatric depression propensity based on hearing loss of the old. Audiology, 1(1), 51-58.

Ciorba, A., Bianchini, C., Pelucchi, S., \& Pastore, A. (2012). The impact of hearing loss on the quality of life of elderly adults. Clinical Interventions in Aging, 7, 159-163.

Clark, J. G. (1981). Uses and abuses of hearing loss classification. American Speech-Language-Hearing Association, 23(7), 493-500.

Ferrari, S., Monzani, D., Gherpelli, C., MacKinnon, A., Mongelli, F., Federici, G., ... \& Galeazzi, G. M. (2019). Acquired hearing loss, anger, and emotional distress: the mediating role of perceived disability. The Journal of nervous and mental disease, 207(6), 459-466.

Gates, G. A., Cooper, J. C. Jr., Kannel, W. B., \& Miller, N. J. (1990). Hearing in the elderly: the Framingham cohort, 1983-1985. Part I. Basic audiometric test results. Ear and Hearing, 11(4), 247-256.

Goman, A. M., \& Lin, F. R. (2016). Prevalence of hearing loss by severity in the United States. American Journal of Public Health, 106(10), 1820-1822.

Han, W., Lee, D., Koo, M., \& Kim, J. (2015). Questionnaires for the hearingimpaired adults and elderly: A systematic literature review. Audiology and Speech Research, 11(1), 3-16.

Hong, B., \& Lee, J. (2002). Hearing threshold and hearing handicap of the elderly with presbycusis. Korean Journal of Communication \& Disorders, $7(1), 214-233$.

Humes, L. E., \& Christopherson, L. (1991). Speech identification difficulties of hearing-impaired elderly persons: the contributions of auditory processing deficits. Journal of Speech, Language, and Hearing Research, 34(3), 686-693.

Jang, H., \& Jeon, S. (2013). Effects of noise type and signal-to-noise ratio on word recognition performance of adults and children with normal hearing sensitivity. Audiology, 9(2), 137-147.

Kang, Y., Chin, J., Na, D. L., Lee, J., \& Park, J. S. (2000). A normative study of the Korean version of Controlled Oral Word Association Test (COWAT) in the elderly. Korean Journal of Clinical Psychology, 19(2), 385-392.

Kang, Y. (2006). A normative study of the Korean-Mini Mental State Exami- nation (K-MMSE) in the elderly. Korean Journal of Psychology: General, 25(2), 1-12.

Kim, H. N., Kim, S. G., Lee, H. K., Ohrr, H., Moon, S. K., Chi, J., ... \& Yi, S. W. (2000). Incidence of presbycusis of Korean populations in Seoul, Kyunggi and Kangwon provinces. Journal of Korean medical science, 15(5), 580584.

Kim, S. H., \& Yeo, S. G. (2015). Presbycusis. Hanyang Medical Reviews, 35(2), 78-83.

Korea Centers for Disease Control and Prevention (2012). Korea Health Statistics 2008: Korea national health and nutrition examination survey. Cheongju: Korea Centers for Disease Control and Prevention.

Ku, H., \& Kim, J. (2000). Test-retest reliability of the Korean hearing handicap inventory for the elderly (KHHIE). Korean Journal of Communication \& Disorders, 5(1), 133-154.

Ku, H., \& Kim, J. (2010a). A preliminary study for development of the Korean evaluation scale for hearing handicap. Audiology and Speech Research, 6(1), 55-59.

Ku, H., \& Kim, J. (2010b). The study for standardization of the Korean evaluation scale for hearing handicap. Audiology and Speech Research, 6(2), 128136.

Lee, H. (2006). Development and validation of Korean version of trail making test for the elderly persons (Master's thesis). Sungkyunkwan University, Seoul, Korea.

Lee, J., Kang, Y., \& Na, D. L. (2000). Efficiencies of Stroop interference indexes in healthy older adult and dementia patients. Korean Journal of Clinical Psychology, 19(4), 807-818.

Lee, J. H., Cho, S. J., Kim, J. S., Jang, H. S., Lim, D. H., Lee, K. W., \& Kim, H. J. (2010). Korean speech audiometry (KSA). Seoul: Hakjisa.

Lee, J. Y., Hwang, H. K., \& Jang, H. S. (2014). Communication difficulties as a function of hearing sensitivity and speech recognition in elderly with hearing loss. Journal of Rehabilitation Research, 18(1), 331-352.

Lee, S. J. (2018). Effects of cognitive impairment on self-reported hearing handicap in older adults with early-stage presbycusis. Journal of the Korean Gerontological Society, 38(1), 1-14.

Lee, S. J., Kim, H. H., Kim, L. S., Kim, J. H., \& Park, K. W. (2019). Effects of frontal-executive dysfunction on self-perceived hearing handicap in the elderly with mild cognitive impairment. Plos one, 14, e0210014.

Lee, S. J., \& Kim, H. H. (2016). Speech perception difficulties and their associated cognitive functions in older adults. Phonetics and Speech Sciences, 8(1), 63-69. 
Youngmee Lee, et al. • Self-perceived Hearing Handicap in the Elderly with HL

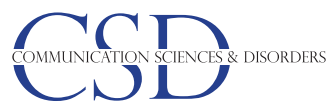

Livingston, G., Sommerlad, A., Orgeta, V., Costafreda, S. G., Huntley, J., Ames, D., ... \& Cooper, C. (2017). Dementia prevention, intervention, and care. The Lancet, 390(10113), 2673-2734.

Lutman, M. E., Brown, E. J., \& Coles, R. R. (1987). Self-reported disability and handicap in the population in relation to pure-tone threshold, age, sex and type of hearing loss. British Journal of Audiology, 21(1), 45-58.

McArdle, R. A., Wilson, R. H., \& Burks, C. A. (2005). Speech recognition in multitalker babble using digits, words, and sentences. Journal of the American Academy of Audiology, 16(9), 726-739.

Morrell, C. H., Gordon-Sarant, S., Pearson, J. D., Brant, L. J., \& Fozard, J. L. (1996). Age- and gender-specific reference ranges for hearing level and longitudinal changes in hearing level. Journal of the Acoustical Society of America, 100(4), 1949-1967.

Park, S. N., Han, G. C., Cho, Y. S., Byun, J. Y., Shin, J. E., Chu, H. S., ... \& Choi, J. Y. (2011). Standardization for a Korean version of hearing handicap inventory for the elderly. Korean J Otorhinolaryngology-Head and Neck Surgery, 54(12), 828-834.

Pichora-Fuller, M. K., Schneider, B. A., \& Daneman, M. (1995). How young and old adults listen to and remember speech in noise. Journal of the Acoustical Society of America, 97(1), 593-608.

Sheikh, V. I., \& Yesavage, V. A. (1986). Geriatric Depression Scale (GDS): recent evidence and development of shorter version. In T. L. Brink (Ed.), Clinical Gerontology: A guide to assessment and intervention (pp. 165-174). New York, NY: New York Haworth Press.

Shojaei, E., Ashayeri, H., Jafari, Z., Dast, M. R. Z., \& Kamali, K. (2015). Effects of signal to noise ratio on the speech perception ability of older adults. Medical Journal of the Islamic Republic of Iran, 30, 1-7.

Souza, V. C., \& Lemos, S. M. A. (2015). Tools for evaluation of restriction on auditory participation: systematic review of the literature. CoDAS, 27(4), 400-406.
Statistics Korea. (2018). Populatsion and hosing census. Retrieved from http:// kostat.go.kr/portal/korea/kor_nw/1/2/6/index.board?bmode=read\&aSeq= 373873.

Stewart, M., Scherer, J., \& Lehman, M. E. (2003). Perceived effects of high frequency hearing loss in a farming population. Journal of the American Academy of Audiology, 14(2), 100-108.

Uchida, Y., Sugiura, S., Nishita, Y., Saji, N., Sone, M., \& Ueda, H. (2019). Agerelated hearing loss and cognitive decline-the potential mechanisms linking the two. Auris Nasus Larynx, 46(1), 1-9.

Ventry, I. M., \& Weinstein, B. E. (1982). The hearing handicap inventory for the elderly: a new tool. Ear \& Hearing, 3(3), 128-134.

Weinstein, B. E., \& Ventry, I. M. (1983). Audiometric correlates of the hearing handicap inventory for the elderly. Journal of Speech and Hearing Research, 48(4), 379-384.

WHO. (1980). International classification of impairments, disabilities and handicaps: a manual of classification relating to the consequences of disease. Geneva: World Health Organization.

WHO. (2001). International classification of functioning, disability and health. Geneva: World Health Organization.

Wu, Y. H., Stangl, E., Chipara, O., Hasan, S. S., Welhaven, A., \& Oleson, J. (2018). Characteristics of real-world signal-to-noise ratios and speech listening situations of older adults with mild-to-moderate hearing loss. Ear and Hearing, 39(2), 293-304.

Yesavage, J. A., Brink T. L., Rose, T. L., Lum, O., Huang, V., Adey, M., \& Leirer, V. O. (1983). Development and validation of a geriatric depression screening scale: a preliminary report. Journal of Psychiatric Research, 17(1), 3749.

Zekveld, A. A., George, E. L. Houtgast, T., \& Kramer, S. E. (2013). Cognitive abilities relate to self-reported hearing disability. Journal of Speech, Language, and Hearing Research, 56(5), 1364-1372. 
Appendix 1. Korean version of Hearing Handicap Inventory for the Elderly (K-HHIE)

본 설문지는 청력 이상으로 인한 불편함을 측정하기 위한 것입니다. 각각의 질문에 네, 가끔, 아니오 라고 답해주십시오. 귀하의 청력 이상을 감추기 위해 질문을 건너 뛰 지 말아주십시오.

\begin{tabular}{|c|c|c|c|c|}
\hline No. & 문항 & 예(4) & 가끔(2) & 아니오(0) \\
\hline S-1 & 청력 이상으로 전화를 원하는 것보다 덜 사용합니까? & & & \\
\hline $\mathrm{E}-2$ & 청력 이상으로 새로운 사람을 만날 때 난처하십니까? & & & \\
\hline$S-3$ & 청력 이상으로 여러 사람들과 함께 있는 것을 피합니까? & & & \\
\hline$E-4$ & 청력 이상으로 짜증이 납니까? & & & \\
\hline$E-5$ & 청력 이상으로 가족들과 대화할 때 좌절감을 느낍니까? & & & \\
\hline S-6 & 청력 이상으로 모임에 참석했을 때 어려움을 느낍니까? & & & \\
\hline$E-7$ & 청력 이상으로 스스로 "바보스럽다" 또는 "멍청하다"고 느끼신 적이 있습니까? & & & \\
\hline S-8 & 누군가 속삭일 때 알아듣기가 어렵습니까? & & & \\
\hline E-9 & 청력 이상으로 스스로 장애가 있다고 느낍니까? & & & \\
\hline S-10 & 청력 이상으로 친구, 친척, 이웃들을 방문할 때 어려움을 느낍니까? & & & \\
\hline$S-11$ & 청력 이상으로 종교 집회에 원하는 것보다 덜 참석합니까? & & & \\
\hline $\mathrm{E}-12$ & 청력 이상으로 성격이 과민해졌습니까? & & & \\
\hline$S-13$ & 청력 이상으로 친구, 친지, 이웃들을 원하는 만큼보다 덜 방문하게 됩니까? & & & \\
\hline $\mathrm{E}-14$ & 청력 이상으로 가족들과 말다툼을 하시게 됩니까? & & & \\
\hline S-15 & 청력 이상으로 TV나 라디오를 들을 때 어려움을 느낍니까? & & & \\
\hline S-16 & 청력 이상으로 쇼핑을 원하는 것 보다 덜 합니까? & & & \\
\hline $\mathrm{E}-17$ & 청력 이상이나 이로 인한 어려움으로 실망한 적이 있습니까? & & & \\
\hline $\mathrm{E}-18$ & 청력 이상으로 혼자 있고 싶다고 느낍니까? & & & \\
\hline S-19 & 청력 이상으로 가족들과 대화를 덜 하게 됩니까? & & & \\
\hline $\mathrm{E}-20$ & 청력 이상이 귀하의 개인 생활이나 사회생활을 제한하거나 방해한다고 느낍니까? & & & \\
\hline S-21 & 청력 이상으로 친척이나 친구들과 식당에 있을 때 어려움을 느낍니까? & & & \\
\hline $\mathrm{E}-22$ & 청력 이상으로 우울하다고 느낍니까? & & & \\
\hline S-23 & 청력 이상으로 TV나 라디오 청취를 원하는 것보다 덜 하게 됩니까? & & & \\
\hline $\mathrm{E}-24$ & 청력 이상으로 친구들과 대화할 때 불편함을 느낍니까? & & & \\
\hline $\mathrm{E}-25$ & 청력 이상으로 여러 사람들과 함께 있을 때 소외된다고 느낍니까? & & & \\
\hline
\end{tabular}

총 점수:

$\mathrm{E}$ 점수:

S 점수: 


\section{국문초록}

\section{난청 노인의 주관적 청각장애지수에 영향을 미치는 변수 탐색}

이영미 ${ }^{1} \cdot$ 박성일 $\cdot$ 이수정 ${ }^{3}$

${ }^{1}$ 이화여자대학교 언어병리학과, ${ }^{2}$ 박성일청각재활센터, ${ }^{3}$ 동명대학교 언어치료청각학과

배경 및 목적: 본 연구에서는 청각장애지수가 경도-중등도인 집단과 심도인 집단 간의 관련 변인의 수행력에 유의한 차이가 있는지를 살펴보고, 청각장애지수와 변인 간의 상관관계를 분석하고, 청각장애지수 중증도를 구분하는 변인이 무엇인지 살펴보고자 하였다. 방 법: 본 연구는 만 65 세 이상의 중등도 및 중등고도 난청 노인 22 명을 대상으로 하였으며, 청각장애지수 중등도 절단 점수에 따라 경도중등도 집단과 심도 집단으로 구분하였다. 대상자의 청각장애지수는 한국어판 고령자 청력 장애 검사를 사용하여 평가하였으며, 청각 학적, 인지기능, 우울 관련 검사들도 함께 실시하였다. 결과: 대상자의 평균 청력 역치, 소음 조건에서의 문장인지 점수, 우울 점수에서 두 집단 간에 유의한 차이를 보였다. 난청 노인과 관련된 다양한 변인 중에서, 대상자의 평균 청력 역치, 소음 조건에서의 문장인지 점수, 우울 점수가 청각장애지수 간에 유의한 상관을 보였다. 이항 로지스틱 회귀분석 결과, $+5 \mathrm{~dB}$ SNR에서의 문장인지 점수가 난청 노인의 청각장애지수의 중등도를 구분하는 유의한 변인으로 나타났다. 논의 및 결론: 난청 노인의 청력, 소음 조건에서의 말지각, 우울 정도가 주관적인 청각장애지수와 관련이 있는 것으로 나타났으며, 이 중에서도 $+5 \mathrm{~dB} \mathrm{SNR}$ 조건에서의 말지각이 대상자의 청각장애지수의 중 증도를 구분하는 변수였다. 인지기능에 문제가 없는 난청 노인의 재활에서는 청각학 관련 변인의 정확한 평가와 노인성 우울과 관련된 평가를 함께 진행할 필요가 있겠다.

핵심어: 변인, 주관적 청각장애지수, 노인, 중등도 및 중등고도 난청

\section{참고문헌}

강연욱(2006). K-MMSE (Korean-Mini Mental State Examination)의 노인 규준 연구. 한국심리학회지: 일반, 25(2), 1-12.

강연욱, 진주희, 나덕렬, 이정희, 박재설(2002). 통제 단어 연상 검사(Controlled Oral Word Association Test)의 노인 규준 연구. 한국심리학회지: 임 상, 19(2), 385-392.

구호림, 김진숙(2000). 한국 노인성 난청의 청각장애지수(KHHIE)에 관한 검사-재검사 신뢰도. 언어청각장애연구, 5(1), 133-154.

구호림, 김진숙(2010a). 청각장애평가지수(KESHH) 개발을 위한 기초연구. 청능재활, 6(1), 55-59.

구호림, 김진숙(2010b). 청각장애평가지수(KESHH)의 표준화 연구. 청능재활, 6(2), 128-136.

김상훈, 여승근(2015). 노인성난청. Hanyang Medical Reviews, 35(2), 78-83.

박시내, 한규철, 조양선, 변재용, 신정은, 추호석, ... 최재영(2011). 한국어판 고령자 청각 장애 검사(K-HHIE) 설문지의 표준화: 타당도 및 신뢰도 검증.

대한이비인후과학회지-두경부외과학, 54(12), 828-834.

이수정(2018). 초기 노인성 난청자에게 인지장애가 일상생활 듣기 어려움에 미치는 영향. 한국노년학, 38(1), 1-14.

이수정, 김향희(2016). 노년층의 말소리 지각 능력과 관련 인지적 변인. 말소리와음성과학, 8(1), 63-69.

이정학, 조수진, 김수진, 장현숙, 임덕환, 이경원, 김형종(2010). 어음청각검사(Korean speech audiometry). 서울: 학지사.

이정희, 강연욱, 나덕렬(2000). Stroop 간섭 지표들의 효율성 비교: 정상노인집단과 치매집단을 대상으로. 한국심리학회지: 임상, 19(4), 807-818.

이지연, 황혜경, 장현숙(2014). 노인의 난청정도와 단어인지도에 따른 의사소통 어려움. 재활복지, 18(1), 331-352.

이한승(2006). 한국판 노인형 기호잇기 검사의 개발과 타당도 연구. 성균관대학교 대학원 석사학위논문.

장현숙, 전슬기(2013). 성인과 아동의 소음유형 및 신호대잡음비에 따른 단어인지도. 청능재활, 9(2), 137-147.

조맹제, 배제남, 서국회, 함봉진, 김장규, 이동우, 강민희(1999). DSM-III-R 주요우울증에 대한 한국어판 Geriatric Depression Scale (GDS)의 진단적 타당성 연구. 신경정신의학, 38(1), 48-63. 
질병건강관리본부(2012). 2008 국민건강통계: 국민건강영양조사 제 4 기 2 차년도(2008) 결과보고서. 청주: 질병건강관리본부.

천행태, 조소현, 조수진(2005). 노인 난청의 우울성향에 관한 연구. 청능재활, 1(1), 51-58.

최지선, 정원호(2011). 노화성 난청과 보청기 효과. 대한의사협회지, 54(9), 918-924.

최형식(2009). 소음유형과 신호 대 잡음비에 따른 문장인지능력. 한림대학교 대학원 석사학위논문.

통계청(2018). 장래인구 추계. 대전: 통계청.

한우재, 이동욱, 구미승, 김진숙(2015). 난청 성인 및 노인용 설문지에 대한 문헌 분석. 청능재활, 11(1), 3-16.

홍빛나, 이정학(2002). 노인성난청의 청력역치와 청각장애지수. 언어청각장애연구, 7(1), 214-233.

\section{ORCID}

이영미(제1저자, 교수, http://orcid.org/0000-0003-1809-5944), 박성일(공동저자, 원장, http://orcid.org/0000-0001-9474-4876) 이수정(교신저자, 교수, http://orcid.org/0000-0003-0954-5181) 